\title{
Bank Regulation, Capital Ratio Behaviour and Risk Taking in a Simultanious Approach
}

\author{
Hichem Maraghni ${ }^{1}$ \\ ${ }^{1}$ Department of Accounting and Finance, Taibah University, Community College of Khaybar, Kingdom of Saudi \\ Arabia \\ Correspondence: Dr. Hichem Maraghni, Professor Asssitant of Finance, Department of Accounting and Finance, \\ Taibah University, Community College of Khaybar, Kingdom of Saudi Arabia. Tel: 966-56-451-3193.
}

Received: October 1, 2016

Accepted: October 11, 2016

Online Published: December 14, 2016

doi:10.5430/ijfr.v8n1p43

URL: http://dx.doi.org/10.5430/ijfr.v8n1p43

\begin{abstract}
We try to look for an answer to the simultaneous impact of changes in capital ratio at risk taking incentive for Tunisian banks under regulation pressure. Our analysis is based on a structural model of two simultaneous equations, originally developed by Shrieves and Dahl (1992), and applied to ten Tunisian universal banks and covers the period from 1990 to 2012 by panel data. The results show firstly, that regulatory pressure led to the adoption of an adequacy required capital does not imply a decrease or an increase in the incentive in risk-taking and secondly that the institutional and legal mechanism shows a positive and significant effect on the level of capital ratio. Regulatory pressure seems to have the desired effect on the behavior of banks on the side of capital. Any change in the level of risk does not induce any effect on the level of capital ratio for all the period of our analysis. Tunisian banks have a preference for risk, but the effort of capitalization is still insufficient. This behavior confirm the existence of moral hazard in banks caused by the safety net and the assistance for the protection guaranteed by the Central Bank. Moreover, by strengthening their capital levels, these banks reduce significantly their incentive to take risks.
\end{abstract}

Keyswords: bank prudential regulation, risk taking, capital ratio behavior, simultaneous approach, Basle accord II and III

\section{Introduction}

The objective of our paper is to investigate the simultaneous impact of changes in capital ratio from the level of risk-taking by Tunisian banks under the influence of regulatory pressure in terms of prudential capital requirement. The analysis is based on a structural model to two simultaneous equations and panel data originally developed by Shrieves and Dahl (1992). The impact of the regulation on banks' risk-taking is with a considerable interest and raises many questions given its importance to financial stability and the protection of financial institutions and rushes against risks that threaten banking business as a whole. The results of theoretical and empirical work on this topic remain controversial. We found that there is no consensus in the literature on the impact of capital requirements on risk-taking of banks and vice versa.

Our empirical contribution tries to explain the unexpected effects caused by regulatory capital requirements on the behavior of the bank and inversely, it seeks more effective means of supervising banks that display different capital structures. It is important to remember that, first, most empirical knowledge based on simultaneous equation models and addressing the link between risk and bank capital, have emerged with Koopmans (1950), Hood and Koopmans (1953) and Klein (1955). Then, given its range of specifications have been improved by the contribution of Arellano and Bond (1991) and Dahl and Shrieves (1992) to obtain a better estimation and understanding of the problem of endogeneity and multiple collinearity. These authors used the generalized method of moments (GMM), and particularly the techniques of 2SLS and 3SLS. In this article we decide to use the method of Last Three Square (3SLS) to estimate our model developed in equations (I.5.1) and (I.5.2), which will later be exhibited. Our structural model seeks to explain the direct and simultaneous endogenous potential impact of each component ( $\triangle \mathrm{CAR}$ and $\Delta$ RISK) as exogenous variables. This is likely to enable us to jointly identify the unanticipated impact.

This paper will be structured as follows: after introducing this article, the first section will be devoted to the assumptions underlying forward, then to the presentation of variables and the framework for analysis and to the econometric specification. In the second section, we will proceed to do a statistical description of our panel, focus on 
the correlation matrix of variables and present the expected signs of the model parameters. The estimation results of the relationship between changes in the ratio of capital and changes in the level of risk in simultaneous equations, by three periods: (PT: 1990-2012), (SP1: 1990-2000) and (SP2: 2001 -2012), are exposed and analyzed throughout the third section. The position of our results compared to those found by other authors will be presented towards the end of this final section.

\section{Assumptions, Variables and Econometric Specification}

\subsection{Assumptions}

Changes in bank capital firm level are associated with various behaviors of risk-taking based on prudential regulation designed to limit bank runs. In fact, the hypothesis to be advanced is around explaining the relationship between simultaneous capitalization, the overall risk bank under the impact of regulatory pressure. Other assumptions are also built to highlight the relationship of endogenous variables with other exogenous mentioned in the literature, among others, we cite the size of the banking firm, assets profitability ratio, the ratio of margin Net interest and the ratio of non-performing loans.

On the one hand the behavior of the regulatory and supervisory authorities will be an important factor in guiding the adjustment reaction between the equity and the banks' risk level. This question is explored, mainly in the work of Shrieves and Dahl (1992), Jacques and Nigro (1997), Aggarwal and Jacques (1998) and Ediz et al (1998) Godlewski (2005) and Lin et al (2013). On the other hand, regulators are encouraging banks to increase their level of capital ratios or proportionally according to the degree of risk involved in their business portfolios. The following six hypotheses were proposed to predict the expected reactions of the different variables used in the model (I.5), for the entire period of analysis.

Hypothesis 1 (H1): A change of the capital levels and changes in the level of risk simultaneously exhibit a negative association. A nonlinear relationship is also provided between the two proxies. If one refers to the results of Blum (1999) and Saadawi (2010), we can say that when a bank meets the regulatory solvency requirements, then any increase in its capitalization must be followed by a decline in incentives for risk-taking. Simultaneously, an increase in risk-taking is usually accompanied by a consolidation of its capital levels. On the basis of his arguments we propose to test this first hypothesis.

Hypothesis $2(\mathrm{H} 2)$ : The expected relationship between the level of capitalization and asset quality in terms of output is assumed to be positive. In particular, this hypothesis is supported by the conclusions and arguments found by Rime (2001) Nashane and Ghosh (2001) and Godlewski (2005).

These authors stated the assets profitability ratio varies in the same direction as the ratio of capital since a proportion of own funds of the institution will eventually be made up of deferred income.

Hypothesis 3 (H3): The size of the bank has a negative relationship with the level variation ratio of capital and simultaneously it is negatively related with changes in the level of risk (Positive with IR). Van Roy (2006) testified that the effect size is one determinant of the change in capital and risk in banks. Moreover, the size of the property is interpreted by Demsetz and Starhan (1997) as a rigorous indicator of portfolio diversification, allowing to operate with significant leverage and deal with riskier activities. Besides, Konishi and Yasuda (2004) pointed out that the large banking firms are more diversified and generally have a lower level of risk. Stiroh (2006) and Ediz et al (1998) highlight the existence of a negative impact from the size and probability of bankruptcy which certifies the effect of diversification.

Hypothesis 4 (H4): We expect the share of net bank interest margin in the total assets is positively correlated with the level of capital ratio and negatively associated with the level of risk. The reasoning behind the setting of this assumption is based on the contribution of Kunt and Huizinga-Demirguc (1999) who ruled on the significant and positive impact of regulatory capital requirements on net interest margins in commercial banks. They argue, too, that when the last record in capital ratios above the required prudential standard, they will be able to cope with relatively high financing costs due to the lack of potential bankruptcy costs supported by their comfortable intermediation margins. According to Santos (2001), the required prudential restrictions on banking require credit institutions to hold a high level of equity. This reaction is conducive to an improvement in their intermediation balances that will cover overhead and operating costs particularly. Furthermore, the conclusions of Rajhi and Gassouma (2011) fall within the same framework as this hypothesis (H4). Indeed, they have highlighted the positive impact of the net interest margin on the discretionary adjustment of the level of regulatory capital by banks possess and they showed that each increase in the ratio of net interest margin likely to approve the increase in regulatory capital more importantly an increase in the level of economic capital. 
Hypothesis 5 (H5): Regulatory pressure has a positive effect on banks' capitalization level, while its impact on the risk level to be determined. As this is an important assumption based on what our research question, its progress was focused essentially on the work of Blum (1999) and Heid et al (2006) who analyzed the relationship between the regulation of bank capital and taking risks in a dynamic framework. They found a recurring effect. Several other works dealing with the impact of regulatory pressure on the behavior of incentive to risk taking leading to controversial results. Indeed, on one hand, the authors believe that banking regulation is a source of moral hazard and encourage credit institutions to adopt risky behavior and engage in uncertain projects. On the other hand, many theorists confirm the essential role of regulation and banking supervision in the prevention and reduction of the level of risk.

Hypothesis 6 (H6): The relationship between the ratio of non-performing loans and the change in the general level of risk the bank is expected with a positive sign (negative link with $\triangle$ RISK variable). In the same line of work Calem and Rob (1999), we believe that the level of risk may increase gradually as the distributed volume credits is ranked among the qualified bad bad and doubtful debts. Saadawi (2010) found that once the desired level of capitalization sufficiently covers the risks, an additional incentive for risk taking is provided from these bank companies which pushes them to reconstruct their credit portfolios by assets non-performing and irrecoverable majority.

\subsection{Variables and Analytical Framework}

All variables were basically inspired by earlier work by Shrieves and Dahl (1992), Jacques and Negro (1997) and Agrawal and Jacques (1998 and 2001), Nachane and Ghosh (2001), Rime (2001) Godlewski (2005) Van Roy (2005), and Matejašák Teplý (2009) and Camara (2010). The two equations (I.5.1) and (I.5.2) of our model, predict that changes in equity and risk are based on desired levels and capital adequacy targets and risk and delayed values of these variables Besides all the explanatory exogenous factors to be defined and presented in detail. Recall that the variable relating to regulatory pressure is one of our main concerns in this article reflects the view that bank institutional environment. She was chosen as defined by Godlewski (2004), Heid et al (2004), Van Roy (2005) and Matejašák and Teplý (2009). Other variables have been introduced by these authors but we omitted them because they treated the specific geographical and other dimensions of analysis that context we do not see the need to introduce in our specification. Being a model of two simultaneous equations, it has two endogenous variables and eight exogenous variables among which, those with a delay of one year.

CAR: It is the solvency ratio or adequacy of regulatory capital. It is the ratio between the prudential net equity of the bank (base and complementary) and weighted bank assets or adjusted for different risk classes . This ratio cannot be calculated directly from the financial statements, is generally issued by banks in their annual reports. As highlighted Powell (2004), this ratio expresses significantly the level of capital of the bank and is applied by most banking systems internationally since it was adopted in Basel II. Under the current regulatory management standard in Tunisia, the value of this ratio must be greater than ( $8 \%$ ). This variable was introduced as $\triangle$ CARit variation as endogenous component and elsewhere in a delayed form or Carit-1. This is a measure that has become very mentioned in the literature, from the introduction of the international standard established by the regulatory authorities. As highlighted by Jacques and Nigro (1997), Aggarwal and Jacques (1998), by Ediz, Michael and Perrandin (1998), Saadawi (2010) and Lin et al. (2013), the adoption of this ratio is interesting because it is a solvency indicator for credit institutions that helps to situate their level of capitalization. In fact, a high level of this ratio indicates a lower risk, we anticipate that the expected sign for $\triangle \mathrm{CAR}$ variable in our model will be positive. By cons, other authors found that the sign of this variable may be negative when adopting the reasoning of the excessive risk taking of properly capitalized banks.

\section{CAR $=$ Capital (Net prudential) $/$ Risk Weighted Asset}

ROA: This is the ratio of return on assets, calculated from the financial statements of each bank over the period of analysis. It is an indicator that detects the quality of assets held by each institution. This variable is included in the equation of the variation in the ratio of capital and we believe that a high value of this ratio indicates a high performance bank and, therefore, a positive sign is expected in our model, as indicated by Rime (2001) and Heid et al (2004) respectively for the Swiss and German banks. Matejašák and Teplý (2009) and Van Roy (2005) used this variable, and they assumed that if the bank increases the ratio by allocation of unallocated profits instead of a new share issue, while the expected relationship can be positive.

$$
\text { ROA = Net Profit / Total Assets }
$$

SIZE: The bank's size can be a determining factor in explaining the behavior of capital ratios. This variable is calculated by the natural logarithm of the total assets of the bank to capture the effect size. It was introduced in both 
equations of our model (in terms of capitalization and level of risk). We recognize that the size is negatively related with the change in the capital and in parallel it is also negatively related with changes in the level of risk associated positively with ( $\Delta \mathrm{IR}=\Delta \mathrm{RISK})$. Indeed, Matejašák and Teply (2009), Shrieves and Dahl (1992) Godlewski (2004), Murinde and Yassen (2004), Hassan and Hussain (2006) and several other authors have found that the size influences the target levels risk and capital are seen close connection with the concept of diversification of the business portfolio, the nature of investment opportunities or with own characteristics to banks combined with flexible access at an improved level of equity. This argument is confirmed by Aggarwal and Jacques (1998) for a sample of US banks. For Acharya (2002), large credit institutions are generally more diversified and stronger. This is confirmed by the principle of "too big to fail". While the findings of Van Roy (2005), in this sense, showed that large banks more comfortably bear the costs of risks and benefit from certain flexibilities to the authorities when they want to increase their capital. The sign of the variable size effect exhibits a negative meaning associated with changes in levels of risk and capital.

$$
\text { SIZE }=\text { Ln (Total Assets) }
$$

SPREAD: This variable represents the activity of traditional banking intermediation and measures the share of net bank interest margin in all the bank's assets. Calculated directly from the income statements of the institutions in question, this variable was used by Godlewski (2004), Van Roy (2005), Jabnoun (2006), Saadawi (2010), Rajhi and Gassouma (2011), in their contributions for other similar context analysis. An increase in the level of capital can positively stimulate the ratio of net margin through a reduction in the cost of capital and by an additional incentive to take risk and shareholders may elect a more uncertain behavior. This reasoning has been adopted by the contribution Agrawal and Jacques (1998). As proposed by Barth et al (2006), we decided to introduce this variable in our specification because it is a ratio that covers the cost of risk and contributes significantly to improving the level of the bank's profits. We expect, as in the fourth case, a positive sign of this variable on the change in the ratio of capital and a negative on the level of risk.

\section{SPREAD $=$ Interrest rate Margin / Total Assets}

RISK: in the case of a measurement variable of the overall bank risk, the choice seems to be largely debatable queries related work, previous literature suggests several alternatives and each measurement method can arouse singular criticism. First, if one follows the work lined Boyd and Graham (1986), Hannan and Hanweck (1988), and Goyeau Tarazi (1992), Mercieca et al. (2007), Sinkey (1999), and Awdeh et al. (2011), then this variable will be estimated by calculating an overall risk index recorded (IR) of the bank view that encompasses the main sources of risk that most threaten the banking industry. Indeed Goyeau and Tarazi (1992) note that a high value of this index corresponds to a relatively low risk and they also provide a breakdown of this indicator in a risk-adjusted profitability component and another as degrees of coverage portfolio risk. Sunirand and Goodhart (2003) applied the index to illustrate the problems related to risky behavior of firms and banking contagion relationships over prudential requirements. After reading the contributions of Kaddour et al. (2010), Mamoghli and Dhouibi (2009), Maraghni and Rajhi (2001), McAllister and McManus (1993) and Liang and Rhoades (1991), we can suggest that a rigorous risk indicators to measure the index failure (Zscore (IR)). The latter introduced in our specification has been the subject of several other contributions to better understand the possible relationship between the level of risk and regulatory practice in capital. We expect this measure to be positively related to risk as higher provisions are usually accompanied by a default probability particularly intense, so it is a good indicator of overall risk of the bank.

The risk index is: $\mathrm{RI}=[\mathrm{E}(\mathrm{ROA})+\mathrm{CAR}] / \sigma(\mathrm{ROA})$ with $\mathrm{E}(\mathrm{ROA})$ and $\sigma(\mathrm{ROA})$ are the mean and standard deviation of the return on assets respectively (CAR) is the capital ratio defined above. Moreover, and as defined by Heid et al (2004), Ediz et al (1998), Jacques and Nigro (1998-2002), Aggarwal and Jacques (1998), Murinde and Yassen (2004), Hassan and Hussain (2006), Van Roy (2005) and Nachane and Ghosh (2001) and Matejašák and Teplý (2007), the RISK variable is determined by the ratio of assets adjusted for risk on total assets (RWA / TA). A positive correlation of the latter with the risk has been detected and verified by Berger (1991-1995). The theoretical basis for the use of this arbitrary measurement variable risk based on the fact that the risk of the portfolio is essentially determined by the asset allocation according to different class of risk. It is important to remember that many others have opted for another indicator to detect the risk level in similar work. This is the ratio of non-performing loans to total loans reported particularly introduced in contributions Godlewski (2005) and Ben Hmida Bouri (2006), Behr et al. (2009), Jokipii and Milne (2010), Agoraki et al. (2010) and Lin et al. (2013) more recently. In our model we have chosen to calculate the risk index (RI) to estimate the overall risk level of the banks in our sample in the form of variation ( $\triangle$ RISKit) and second with one-year delay (Riski, t-1). As Saunders et al. (1990), Demsetz and Strahan (1997), Esty (1998) and Laeven and Levine (2009), we estimate the expected sign of 
this variable seems controversial in the theoretical and empirical literature anterior and can be either negative or positive. It remains to consider its sign in the context of our estimate for the ten Tunisian banks retained. The bank's risk index is calculated as follows:

$$
\mathrm{RISK}=\mathrm{RI}=[\mathrm{E}(\mathrm{ROA})+\mathrm{CAR}] / \sigma(\mathrm{ROA})
$$

REG: This is an exogenous variable is among the most important measures to capture the impact of regulatory pressure and legislative requirements on capital, from the Basel Accord, which might influence funding levels and level of risk. Adopted by Heid et al. (2003), Van Roy (2005) Cannat and Quagliariello (2006), Matejašák and Teplý (2009), Saadawi (2010) Awdeh et al (2011) and Bouri and Ben Hmida (2011) in their respective work, this variable takes two possible values and is the most used because it takes into account the volatility of equity. The majority of these authors considered explicitly that the increase in capital is an expensive operation, shareholders prefer to hold in excess of the minimum amount required by the regulations in force when these funds are very volatile. Saadawi (2010) and Awdeh (2011) support the hypothesis that if the banks who comply with the minimum capital requirement, feel necessarily threatened by legal restrictions, forcing them to consolidate their regulatory capital and control their behavior risk. By following the definition of Van Roy (2005) we used this variable in our model to detect the effect of regulatory pressure. Rime (2001) Nachane and Ghosh (2001), and Pentiris Elosegui (2002), Darine (2008) and Ediz et al. (1998) found a result that demonstrates a positive impact.

We expect a positive effect of the latter on the level of capitalization, while the effect on the risk level to be determined. Godlewski (2005) and Lin et al. (2013) have also adopted this variable and found a negative impact of this variable on the level of risk. Thus, we assume that if at the end of a year ( $t)$, a bank displays a solvency ratio (CAR) below the regulatory minimum (Min REG), to which we add the standard deviation ( $\sigma$ CAR) CAR ratio then it will be very likely that during the next year $(t+1)$, the bank suffered disciplinary measures of order.

For a bank (i) and after a year (t) Variable regulatory pressure (REG) is defined as follows:

$$
\begin{array}{ll}
\text { REG }_{\mathrm{i}, \mathrm{t}}=\left[\operatorname{Min}_{\mathrm{REG}}+\sigma \mathrm{CAR}_{\mathrm{i}}\right]-\mathrm{CAR}_{\mathrm{i}, \mathrm{t}} & \text { if } \mathrm{CAR}_{\mathrm{i}, \mathrm{t}} \leq \operatorname{Min}_{\mathrm{REG}}+\sigma \mathrm{CAR}_{\mathrm{i}} \\
\text { REG }_{\mathrm{i}, \mathrm{t}}=\mathbf{0} & \text { if } \mathrm{CAR}_{\mathrm{i}, \mathrm{t}}>\operatorname{Min}_{\mathrm{REG}}+\sigma \mathrm{CAR}_{\mathrm{i}}
\end{array}
$$

LLOSS: This is an integrated variable in the equation for change in risk across the ratio of non-performing loans (NPL) reported on total loans granted. These data are not accessible in part, difficult to calculate, we collected them from database sources on the Tunisian banking sector from Finland (UN) and Canada (Bankscope) over the period (1990- 1999). According Rime (2001), and Quagliariello Cannat (2006), the relationship of this variable with risk taking depends on the definition of risk adopted and they expected it to be positive. Jacques and Negro (1998), Saadawi (2010), Bouri and Ben Hmida (2006 and 2011) and Matejašák and Teplý (2009) also included this variable in their work and they detected a positive relationship between the volume of bad debts on the volume of loans with the overall risk level of the bank. Given the nature of the risk indicator (IR) we have chosen, we expect that the relationship between LLOSS and $\triangle$ RISK is negative. This result was supported by the outcomes of Ramassur and Polodoo (2011).

\section{LLOSS $=$ Non Performing Loans $/$ Total Asstes}

$\Delta$ RISK and $\Delta$ CAR: This is the change in capital and risk treated simultaneously with time and for all banks in our sample. The relationship between these two variables is central to our problem. Changes in the level of capital as well as that of risk are both endogenous variables that adjust dynamically simultaneously. As Shrieves and Dahl (1992), Ghosh et Nashane (2001), Rime (2001), Godlewski (2005) Lin et al (2013) and Awdeh et al (2011) as well as for other work on the partial adjustment We included every instrument on the right side of the equation, which will allow us to control these variables simultaneously. We believe that an increase in risk implies a lower level of capitalization. The shareholders of adequately capitalized banks, showers risks generally accepts a higher risk level that could encourage them to change their behavior to avoid disciplinary restrictions of capital regulations. All these variables, chosen on the basis of the theoretical and empirical literature dealing with the same problem but in different analysis frameworks will be introduced into the model to simultaneous equation originally developed by Dahl and Shrieves (1992) and which was echoed by several other authors in different research contexts. Our model is specified and estimated thereafter over a period of twenty three years and ten commercial banks (universal) Tunisian. The period will then be divided into two according to our investigations to refine benefits our results.

\subsection{Econometric Specification and Partial Adjustment}

The econometric specification we will develop was practically used by more than 27 pioneering contributions in different contexts. Indeed, the model was treated for similar studies in emerging countries such as those of 
Godlewski (2005), Ayachi (2006), Hussain and Hassan (2006), Saadawi (2010), the United States found contributions Jacques and Nigro (1997), Aggarwal and Jacques (1998), and Matejašák Teplý (2009), Lin et al (2013). Furthermore, Ediz et al (1998) exposed and estimate a similar specification for British banks in Germany and Swisse found the work of Heid et al, respectively (2004) and Rime (2001). In India, work on the same issue were were treated with Nachane and Ghosh in 2001. The same basic model was estimated on the basis of a sample of countries in the MENA region, among others, Darine (2006) Awdeh (2011) and Solhi and Mehdi (2012) who exhibited a similar specification and estimated by the partial adjustment technique. The banks of the countries of the European Union have also been studied through this model the work of Van Roy example is cited (2005), Camara (2010) and Matejašák and Teplý (2009) and in conjunction with US banks.

Other empirical work has been done on the Tunisian banking firms, including those by Bouri and Ben Hmida (2006 and 2011) and Rajhi and Mahwechi (2002). There are more recently, to institutions in Mauritania, and the contribution of Polodoo Ramassur (2011), on banks in Jordan is quoted article Zubi et al (2011) in Lebanon and the Caribbean Islands as one refers respectively the contribution of Awdeh et al (2011) and Mitchell (1998), without Finally mention the recent reports Mongid and Al (2012) to eight countries in Asia (Indonesia, Malaysia, Thailand, Philippines, Singapore, Cambodia, Brunei and Vietnam).

We note that this specification is so important it appears practically in many empirical studies abroad échèle. It is in this line that we will also expose our model after fixing our assumptions and set all the variables. The simultaneous equations model, we will estimate includes two endogenous variables are the level of bank capitalization and change in the overall level of risk.

Theoretically these two are interdependent and proxy vary simultaneously and each change in the funding ratio is likely to cause an adjustment in behavior of risk-taking and vice versa, ie a change in the risk level is supposed to encourage the bank to adjust the level of its capital ratio. This model is derived from the system of equations, which refers to the work of Shrieves and Dahl (1992), which, in their turns, were inspired by the contributions of Peltzman (1970), Marcus (1983), Wall and Peterson (1987). If one refers to the work of Arellano and Bond (1991), we will opt for a first order differentiation to remove any suspected correlations following the effect of specific endogenous variables. RISK * and CAR * are the optimal levels of capitalization and risk-taking that bank executives wish to achieve, and together linearly dependent on a set of explanatory variables and exogenous that reflect the process of own decision for the establishment. It is assumed that in the long term the bank seeks to achieve these target levels by taking a part-discretionary and dynamic time-adjusted level of capital and of the overall risk index. We also assume that the bank is not able to instantaneously reach target levels of capitalization and risk but it does so partially, which requires the introduction of the coefficients associated with the partial adjustment of these two variables are respectively $(\alpha)$ and $(\beta)$. These are two parameters which measure the speed of adjustment, their values vary between zero and unity. During each year (t), the optimal change in capital and the risk of a bank (i) is explained by the difference between the optimal levels that the bank wants to achieve, and are CAR ** RISK and observed levels during the previous year respectively denoted CAR t-1 and t-1 RISK. We can then write:

$$
\begin{aligned}
& \Delta \text { CAR }_{\mathrm{i}, \mathrm{t}}=\alpha\left(\mathrm{CAR}^{*}-\mathrm{CAR}_{\mathrm{t}-1}\right) \\
& \Delta \text { RISK }_{\mathrm{i}, \mathrm{t}}=\boldsymbol{\beta}\left(\text { RISK* }^{*} \text { RISK }_{\mathrm{t}-1}\right)
\end{aligned}
$$

In addition to discretionary changes in capital and risk, it is necessary to consider other factors external to the bank (At and $\mathrm{Bt}$ ) that influence the capital and risk. We write these relations as well:

$\begin{array}{rlcl}\Delta \text { CAR }_{\mathrm{i}, \mathrm{t}} & =\boldsymbol{\alpha}\left(\mathrm{CAR}^{*}-\mathbf{C A R}_{\mathrm{t}-1}\right) & +\mathbf{A}_{\mathrm{t}} \\ \Delta \text { RISK }_{\mathrm{i}, \mathrm{t}} & =\boldsymbol{\beta}\left(\text { RISK }^{*}-\text { RISK }_{\mathrm{t}-1}\right) & +\mathbf{B}_{\mathrm{t}}\end{array}$

The change of capital and risk depends optimal levels targets specified by the leaders of the bank, the levels recorded in the previous year as well as a set of factors external to the bank noted (At) and (Bt). Besides, it's all of our explanatory variables already defined and discussed above. In final, our econometric model (I.5) two simultaneous equations (I.5.1) and (I.5.2) reads as follows:

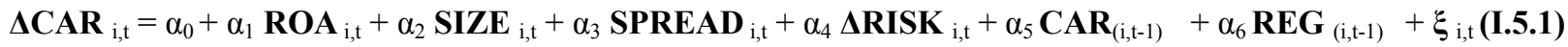

$$
\begin{aligned}
& \Delta \text { RISK }_{\mathrm{i}, \mathrm{t}}=\beta_{0}+\beta_{1} \text { SIZE }_{\mathrm{i}, \mathrm{t}}+\beta_{2} \text { LLOSS }_{\mathrm{i}, \mathrm{t}}+\beta_{3} \text { SPREAD }_{\mathrm{i}, \mathrm{t}}+\beta_{4} \Delta \mathbf{C A R}_{\mathrm{i}, \mathrm{t}}+\beta_{5} \text { RISK }_{(\mathrm{i}, \mathrm{t}-1)}+\beta_{6} \mathbf{R E G}_{(\mathrm{i}, \mathrm{t}-1)}+\mathbf{V}_{\mathrm{i}, \mathrm{t}}
\end{aligned}
$$

The terms $\xi \mathrm{i}, \mathrm{t}$ and $\mathrm{Vi}, \mathrm{t}$ represent the residues of equations in terms of capitalization and the level of risk for each bank (i) and during the year (t). Furthermore, $(\alpha 0)$ and $(\beta 0)$ are the constants related respectively to the two equations. 


\subsection{Pre-test Specification and Estimation}

In the development of our model, we suspected of endogeneity problems related to successful specifications. According to Arellano and Bond (1991), these potential difficulties of endogeneity may be exceeded by a first order differentiation and especially the use of the method of least squares estimation triple (3SLS) considered more robust than lower double squares (2SLS) to solve this kind of econometric ambiguity. We will be part of the tradition of Jacques and Nigro (1997) Shrieves and Dahl (1992), Rime (2001) and Heid et al (2004) and several other authors and we recognize the estimation method according to 3SLS. It is important to remember that some specification tests are necessary and fundamental to achieve more robust econometric results.

These are tested by equation equation realized to confirm the choice of the estimation method chosen. This is the endogeneity test and the identification of the model test. The synthesis of the results will be unveiled in (A) and (B) as follows:

\section{A - Test Durbin-Wu-Hausman Davidson and Mackinnon}

To identify the possible presence of endogeneity problem, use is made of Durbin-tested Wu Haussmann and Davidson and McKinnon (1993) which are in two stages. As a first step, we proceed to the regression of each endogenous variable on all exogenous variables. Then, the residue is recovered from the first regression and are included in the initial model. In our case, we will test the endogeneity of the variable $\triangle \mathrm{CAR} i, \mathrm{t}$ and subsequently that of the variable change in the level of risk $\triangle \mathrm{RISKi}, \mathrm{t}$. Regression $\triangle \mathrm{CARi}, \mathrm{t}$ as a function of (ROAI, $\mathrm{t}, \mathrm{SIZEi}, \mathrm{t}$, SPREADi, t, CP (i, t1), REG (i, t-1), LLOSSi, t, RISK (i, t-1) ) and the term residues $\xi \mathrm{i}$, $\mathrm{t}$ of the equation (II.5.1) gives a Fisher statistic: $F(7,222)=43.04$ with a prob $>F=0.0000$, that is to say a the $1 \%$, higher than the critical value read directly from Fisher's table for a number of observations equal to 230 over the period 1990 to 2012, we have $F(q=7$ and $n k-1=222)$. For all the $t$-Student variables are not significant with $P$-value $>|t|=0.0000$. We can conclude that the results of this test for this variable endogeneity show that the term residues capitalization equation is not significant and so, it confirms the absence of endogeneity problem. Similarly, the regression $\Delta R I S K i, t$ in terms of: (ROAI, t, SIZEi, t, SPREADi, t, CP (i, t1), REG (i, t-1), LLOSSi, t, RISK (i, t-1)) and the term residues V i, $t$ of the equation (I.5.2) gives a Fisher statistic: $F(7,222)=22.91$ with a prob $>F=0.0000$, that is ie a threshold of $1 \%$, higher than the critical value read directly from Fisher's table for a number of observations equal to 230 over the period 1990 to 2012, we have $\mathrm{F}(\mathrm{q}=7$ and $\mathrm{nk}-1=222)$. Then we reject the hypothesis of the presence of endogeneity. For all these T-Student variables are not significant with P-value $>|\mathrm{t}|=0.0000$. We can conclude that the results of the endogeneity test for both endogenous variables show that residues of equations (I.5.1) and (I.5.2) of the variation in the level of risk and capital ratios are not significant and so there is no endogeneity problem in our econometric specification.

\section{B - Conditions of identification}

Requirements for identification of a simultaneous equations model are determined by equation equation and must be detected prior to estimation. The conditions necessary to model identification simultaneous equations applied to our model allows us to point out, firstly, it has two endogenous variables: $\Delta \mathrm{CARi}, \mathrm{t}$ and $\Delta$ Riski, $\mathrm{t}$, ie $\mathrm{g}=2$, also is the number of equations to estimate.

On the other hand, it is composed of nine exogenous variables in addition to the constant (ROA $i$, $t$, SIZEi, $t$, SPREADi, t, $\triangle$ RISKi, t, CP (i, t-1), REG (i, t -1), LLOSS i, t, $\triangle$ CARi, t and RISK (i, t-1)) for each bank (i) and year $(\mathrm{t})$, and $\mathrm{k}=10$. In the first equation, the number of endogenous variable is $\mathrm{g}^{\prime}=1$ while the exogenous variables is $\mathrm{k}=$ 6. Similarly, in the second equation, the number of endogenous variable $\mathrm{g}^{\prime}=1$ while the exogenous variables is $\mathrm{k}=6$. The conditions identification are written in the first and the second equation in the same manner such that:

\section{Equation (I.5.1):}

$$
\begin{aligned}
& {[2-1]=1<[(2-1)+(10-6)]=5} \\
& {[2-1]=1<[(2-1)+(10-6)]=5}
\end{aligned}
$$

\section{Equation (I.5.2):}

We can conclude that the two equations (I.5.1) and (I.5.2) in our model are over-identified and therefore our model itself is logged on. We have the choice to estimate its parameters using either the least square method twice (2SLS) or the least squares method triples (3SLS). For both model equations (I.5), we have to verify the absence of endogeneity problem for all of our samples, and observations over the entire period of analysis from 1990 to 2012. 


\section{Description and Statistical Data}

\subsection{Data Description}

Our sample includes (10) approved credit institutions as universal banks (commercial) Tunisian within the meaning of Law No. 2001-65 of 10 July 2001 - law n ${ }^{\circ}$ 2006-19 of May 2, 2006 and over a period of 23 years, from 1990 until 2012. Initially to prepare our database we collected financial statements of the ten Tunisian banks, all introduced stock exchange in Tunis, ie, balance sheets, income statements, statements of treasuries flows, notes to financial statements and commitments off balance sheets. We obtained these documents, part on magnetic media and another part on supports of bet, based on reports from the Professional Association of Banks and Financial Institutions in Tunisia, reports of the Central Bank of Tunisia and other financial statements have been collected from the African Development Bank.

Specific reports few banks subject to our sample, as well as those of Maxula Exchange, Fitch-rating, report on regulatory supervision in Tunisia and other available and effective banking statistics were also collected to complete the construction of our official database. The list of company names, the structure of capital in late 2012, their dates of introduction on the stock exchange, their level of capitalization MD at December 31, 2012, the shares of loans and deposits, the ten banks in our panel are shown in Table 1 below:

Table 1. List of banks

\begin{tabular}{|c|c|c|c|c|c|c|}
\hline \multirow[t]{2}{*}{ Banques } & \multirow[t]{2}{*}{ Social Name } & \multicolumn{3}{|c|}{$\begin{array}{r}\text { Market part } \\
\text { at 31/12/2012 }\end{array}$} & \multirow[t]{2}{*}{$\begin{array}{c}\text { Capital Structure } \\
2014\end{array}$} & \multirow{2}{*}{$\begin{array}{c}\text { Year of } \\
\text { introduction in } \\
\text { market }\end{array}$} \\
\hline & & FP* & & D & & \\
\hline ATTIJARI & Attijari Bank & 240 & $5,9 \%$ & $8,9 \%$ & Private majority & 1990 \\
\hline BIAT & $\begin{array}{l}\text { Banque Internationale } \\
\text { Arabe de Tunisie }\end{array}$ & 491 & $11,4 \%$ & $14,9 \%$ & Private majority & 1990 \\
\hline BH & Banque de l'Habitat & 411 & $11,8 \%$ & $10,4 \%$ & Public majority & 1992 \\
\hline STB & $\begin{array}{l}\text { Société } \text { Tunisienne de } \\
\text { Banque }\end{array}$ & 514 & $14,9 \%$ & $12,7 \%$ & Public majority & 1990 \\
\hline BNA & Banque Nationale Agricole & 360 & $13,4 \%$ & $13 \%$ & Public majority & 1990 \\
\hline BT & Banque de Tunisie & 445 & $5,5 \%$ & $5,0 \%$ & Private majority & 1990 \\
\hline UBCI & $\begin{array}{l}\text { Union Bancaire pour } \\
\text { le Commerce et l'Industrie }\end{array}$ & 187 & $2,1 \%$ & $3,5 \%$ & Private foreign majority & 1990 \\
\hline $\mathbf{A B}$ & Amen Bank & 351 & $8,4 \%$ & $7,4 \%$ & Private majority & 1996 \\
\hline ATB & Arab Tunisian Bank & 310 & $3,9 \%$ & $8,7 \%$ & Private foreign majority & 1990 \\
\hline UIB & $\begin{array}{l}\text { Union Internationale } \\
\text { des Banques }\end{array}$ & 80 & $4,7 \%$ & $4,4 \%$ & Private foreign majority & 1996 \\
\hline
\end{tabular}

Source: Works Mbarek and Hmaied (2012) and reports Maxula Exchange and APBFT 2012. (FP): * own funds (in million dinars), (C): the share of loans and (D) represents the share of deposits (compared to the sector).

The share of equity, loans and deposits distributed collected ten banks in our sample are relatively large is significant throughout the Tunisian banking system. Indeed these institutions monopolize in them only about $80 \%$ of total equity, loans and deposits of the entire sector. This is a strictly representative sample of the Tunisian banking sector. In addition, most banks making up our sample were introduced in dung from 1990 which coincides with the lower limit of the interval of time on our analysis period (1990 to 2012).

In Tunisia the application of $5 \%$ as a prudential standard on the ratio of regulatory capital was required for all banks from January 2, 1992 and in accordance with the circular to banks No. 91-24 of 17 December 1991. The adoption of the Basel I agreement has been since its inception in 1988. Then it was amended by circular to banks $\mathrm{n}^{\circ} 99-04$ of 19 March 1999, which entered into force December 31, 1999, to become a standard equal to $8 \%$. This standard established by the Basel II agreement was notified and required to Tunisian banks since 1992. The application of these two standards spread over time was adopted belatedly by the Tunisian banks for five years and $5 \%$ eight years for $8 \%$. What matters is the choice of our sample which coincides with the period of the adoption of these two prudential management standards where the justification of choice of the two sub-periods used in our estimate 
namely in period 1: (1990 -2000) and in period 2 (2001 -2012). All accounting data is observed in the financial statements for each financial institution that are published December 31 in each year of the period considered (1990-2012). To calculate the difference first venture capital variables and we have entered the data of 1989.

\subsection{Data Processing and Properties of Descriptive Statistics}

Table 2. Statistical properties of the variables

\begin{tabular}{lccccc}
\hline \multicolumn{1}{c}{ Variables } & $\mathbf{( N )}$ & Mean & SD & Min. & Max. \\
\hline$\Delta$ CAR & 230 & 0.00351 & 0.01747 & -0.09741 & 0.07073 \\
$\Delta$ RISK & 230 & 0.7144 & 3.41824 & -6.06545 & 20.2023 \\
ROA & 230 & 0.005444 & 0.011517 & -0.10351 & 0.03501 \\
SIZE & 230 & 14.81109 & 0.53435 & 12.4643 & 16.8847 \\
CAR & 230 & 0.08256 & 0.03097 & -0.01098 & 0.17482 \\
RISK & 230 & 16.6928 & 9.77708 & -0.59025 & 49.9254 \\
SPREAD & 230 & 0.03631 & 0.021089 & 0.00935 & 0.12913 \\
REG & 230 & 0.015974 & 0.018572 & 0 & 0.11771 \\
LLOSS & 230 & 0.227565 & 0.060468 & 0.12 & 0.32 \\
\hline
\end{tabular}

Source: by Stata 11. N: Number of comments on the analysis period (1990-2012). Min: minimum value observed. Max: The maximum value observed. The sample includes 10 Tunisian universal banks.

The Table 2 presents some information on the statistical properties of the variables studied. We note that the regulatory capital ratio (CAR) stood on average (8.25\%) (standard deviation equal to $3.09 \%$ ) between a maximum value $(17.48 \%)$ and a minimum of another $(-1.09 \%)$. The variation of the ratio $(\triangle \mathrm{CAR})$ between $(\mathrm{t})$ and $(\mathrm{t}-1)$ in this sample is an average of about (0.00351). The low solvency level (regulatory capital ratio) of the ten banks is remarkable and can be explained mainly by the very high amount of risky assets held in their loan portfolios. For example, in 2014 the STB has a very high amount of NPLs of around 2900 Million Dinars. Regarding the index of risk (RISK), it ventilates between (-0.59025) and (49.9254) with a standard deviation of about (9.77708). We notice an average change of the indicator ( $\triangle$ RISK) equal to (0.71444) for 230 observations, to display a maximum value of (20.20237) and minimum (-6.065545). The level of risk among these banks announced heterogeneous between these banks. We can conclude that they are threatened with differing degrees by the global risk or they do not have the same vis-a-vis the risk taken. The ten selected banks recorded an average share of asset profitability ratio (ROA) and the ratio of non-performing loans, respectively, of the order of $0.5 \%$ and $22.75 \%$. It is clear that these banks détiennes average assets bad qualities (receivables, customers ... etc.) or even low profitability. Furthermore, we do not record that the average level of the ratio of net margin of intermediation is relatively small, it amounts to (0.03631) with a dispersion compared to the mean of 0.021089 (standard deviation).

Descriptive statistics of the variables show that on average these banks have sizes that resemble each (12.4643) and (16.8847), with a standard deviation of about (0534). This is a small deviation from the observed average. The natural logarithm of the average assets of these ten banks in the order of (14.81109) over the period 1990 to 2012. The purpose banks in our sample are assumed small size relative to their counterparts in Europe or the United States of America which have been the subject of other similar studies. Indeed, in 2010 the total assets of Tunisian banks weighs only $2.76 \%$ of the total assets of banks in Africa and the first Tunisian bank in terms of total assets is in 45th place in the ranking of African banks.

\subsection{Correlation Matrix and Expected Signs}

In the same context of definition and presentation of variables related to the specification of our model, we turn now to present the correlations between various measures of capitalization levels and those taking the overall risk over the period of 23 years and for the ten selected commercial banks. These calculations can we be helpful in explaining the various determinants of risk and capital in both equations. The Table 3 recounts the following correlation matrix between the variables included in the model. 
Table 3. Correlation matrix

\begin{tabular}{|c|c|c|c|c|c|c|c|c|c|}
\hline Variables & $\mathbf{R O A}_{i, t}$ & SIZE $_{i, t}$ & SPREAD $_{\mathrm{i}, \mathrm{t}}$ & $\mathbf{C A R}_{(\mathrm{i}, \mathrm{t}-1)}$ & $\mathbf{C A R}_{\mathrm{i}, \mathrm{t}}$ & $\operatorname{RISK}_{(\mathrm{i}, \mathrm{t}-1)}$ & RISK $_{i, t}$ & REG $_{(\mathrm{i}, \mathrm{t}-1)}$ & $\operatorname{LLOSS}_{i, t}$ \\
\hline $\mathbf{R O A}_{i, t}$ & 1 & & & & & & & & \\
\hline $\mathbf{S I Z E}_{\mathrm{i}, \mathrm{t}}$ & -0.0589 & 1 & & & & & & & \\
\hline SPREAD $_{i, t}$ & -0.0277 & -0.0577 & 1 & & & & & & \\
\hline $\mathbf{C A R}_{(\mathrm{it},-1)}$ & 0.1366 & 0.2339 & 0.0020 & 1 & & & & & \\
\hline $\mathbf{C A R}_{\mathrm{i}, \mathrm{t}}$ & 0.3585 & -0.2433 & -0.0525 & -0.4596 & 1 & & & & \\
\hline $\operatorname{RISK}_{(\mathrm{i}, \mathrm{t}-1)}$ & 0.0730 & 0.4616 & 0.0039 & 0.5691 & -0.2949 & 1 & & & \\
\hline RISK $_{\mathrm{i}, \mathrm{t}}$ & 0.0341 & 0.0013 & -0.0434 & -0.2430 & 0.3707 & -0.0004 & 1 & & \\
\hline $\mathbf{R E G}_{(\mathrm{i}, \mathrm{t}-1)}$ & -0.1337 & 0.0920 & 0.0249 & -0.5190 & 0.1134 & -0.3905 & 0.0099 & 1 & \\
\hline $\operatorname{LLOSS}_{\mathrm{i}, \mathrm{t}}$ & 0.0400 & -0.6270 & 0.0080 & -0.3216 & 0.2344 & -0.2258 & 0.0569 & -0.0796 & 1 \\
\hline
\end{tabular}

The correlation matrix is calculated with the Stata 11. Over the entire period from 1990 to 2012. The new variables introduced in our model appear in the matrix for each bank (i) and year ( $t$ ).

First, we note that all correlation coefficients between variables are lower (0.7), so we confirm the absence of collinearity problem. Then, the sign of these coefficients is sometimes positive and other negative. The correlation between variable responsible regulatory pressure is relatively low, respectively, with the ratio of capital and the risk indicator. The positive coefficients, respectively, is recorded in (0.1134) and (0.0099). From this matrix, it appears that there is a positive correlation between risk measurement Riski, $t$ and that relating to capital ratio curry, tom. This association is weak and we record a value of the order of coefficient $(0.3707)$, and for the first difference between these two variables RISK (i, t-1) and CAR (i, t-1) it is positive as found in the works of Shrieves and Dahl (2001), Rime (2001), and Quagliariello Cannat (2006), Saadawi (2010), Jokipii and Milne (2010) and Lin et al. (2013). This finding is opposite to that reported by Jacques and Nigro (1997), Ediz et al. (1998), Nashane and Ghosh (2001), and Murinde Yassen (2004) and Mongid et al (2012). They explained the presence of a negative correlation with the cross-sectional variation of preference levels of risk (Cross-sectional risk preferences) or the attitude of banks in the United States vis-à-vis the risk. Indeed, and as explained Hassan and Hussain (2004), banks with low risk aversion tend to choose a low ratio of capital and a high level of risk, while banks with strong risk aversion choose the higher capital ratios at a low level of risk.

Table 4. Expected signs of coefficients

\begin{tabular}{|c|c|c|c|}
\hline Variables & Coefficients & $\begin{array}{c}\text { Variation of capital ratio } \\
\qquad C A R_{i, t}\end{array}$ & $\begin{array}{c}\text { Variationof risk level } \\
\text { ARISK }_{i, t}\end{array}$ \\
\hline $\mathbf{R O A}_{i, t}$ & $\alpha_{1}$ & + & \\
\hline $\operatorname{SIZE~}_{i, t}$ & $\alpha_{2}$ et $\beta_{1}$ & - & + \\
\hline SPREAD $_{\mathrm{i}, \mathrm{t}}$ & $\alpha_{3}$ et $\beta_{3}$ & + & + \\
\hline $\operatorname{CAR}_{(\mathrm{i}, \mathrm{t}-1)}$ & $\alpha_{5}$ & + & \\
\hline$\Delta$ RISK $_{\mathrm{i}, \mathrm{t}}$ & $\alpha_{4}$ & $?$ & \\
\hline $\operatorname{REG}_{(\mathrm{i}, \mathrm{t}-1)}$ & $\alpha_{6}$ et $\beta_{6}$ & + & $?$ \\
\hline $\operatorname{LLOSS}_{\mathrm{i}, \mathrm{t}}$ & $\beta_{2}$ & & - \\
\hline$\Delta$ CAR $_{i, t}$ & $\beta_{4}$ & & + \\
\hline $\operatorname{RISK}_{(\mathrm{i}, \mathrm{t}-1)}$ & $\beta_{5}$ & & + \\
\hline
\end{tabular}

The question mark (?) Means that the expected sign of this variable parameter can be either positive or negative (theoretical controversy about the impact of this variable). Counters (i) and (t) respectively represent bank and year. The $\alpha 1,26$ and $\beta$ coefficients ......6 1.2: are the model parameters. The variables are: ROA: the profitability ratio of assets, SIZE: the natural logarithm of total assets, SPREAD: the ratio of net interest margin on total assets, LLOSS: the ratio of non-performing loans to total loans REG: the variable indicating regulatory pressure. $\triangle$ RISK and $\triangle$ CAR represent the endogenous variables in our model: changes in the level of risk and the level of capital ratio. 
The expected signs of the different parameters of the model (I.5) are fixed so as to express our econometric assumptions already mentioned above. These signs are also provided by Blum and Bischel (2004) and Darine (2008). Other similar studies have provided different signs to those mentioned in the Table 4 . The prediction of these effects differs from a contribution to another based on theoretical assumptions based and set at the beginning of the analysis. It remains to argue every time his choice of signs according to the characteristics of samples object of the econometric analysis. These variables cannot be significant and in this case the expected sign would be a low estimate. In what follows, we will present the results of the estimation of our model for what we Successful for ten Tunisian banks and the three periods already established. The financial and econometric interpretation will focus in more detail particularly on the impact of the change in the capital ratio on the behavior of the overall risk management of banks under regulatory pressure. Towards the end of our interpretations, we will bring together the various conclusions and compare found in the Table 6, with those found in similar work to position our results under the Tunisian context and highlight their relevance more.

\section{Estimation Results of the Relationship between Changes in Capital and Changes in Risk in Simultaneous Equation}

Most of the results of the estimation of our model (I.5) is compiled in the Table 5 below:

Table 5. Results of the model estimation (I.5)

\begin{tabular}{|c|c|c|c|c|c|c|}
\hline \multirow{2}{*}{ Endogenous Variables } & \multicolumn{2}{|c|}{ All period: 1990 -2012 } & \multicolumn{2}{|c|}{ Periode 1: 1990 - 2000} & \multicolumn{2}{|c|}{ Periode 2: 2001 - 2012} \\
\hline & $\triangle \mathrm{CAR}$ & $\Delta$ RISK & $\triangle \mathrm{CAR}$ & $\Delta$ RISK & $\triangle \mathrm{CAR}$ & $\Delta$ RISK \\
\hline \multicolumn{7}{|l|}{ Exogenous Variables } \\
\hline \multirow{2}{*}{$\boldsymbol{R O A}$} & 0.65631 & & 0.06011 & & 0.5087 & \\
\hline & $(7.06)^{* * *}$ & & $(0.23)$ & & $(3.40)^{* * *}$ & \\
\hline \multirow{2}{*}{ SIZE } & -0.00227 & 1.0473 & 0.0020 & -0.6673 & -0.0098 & 3.5403 \\
\hline & $(0.99)$ & $(0.91)$ & $(0.58)$ & $(0.46)$ & $(1.58)$ & $(2.35)^{* *}$ \\
\hline \multirow{2}{*}{ SPREAD } & -0.00054 & -0.0708 & 0.4802 & 4.3384 & -0.0001 & -0.0795 \\
\hline & $(0.83)$ & $(0.24)$ & $(2.24)^{* *}$ & $(0.07)$ & $(0.17)$ & $(0.24)$ \\
\hline \multirow{2}{*}{$C A R_{(i, t-1)}$} & -0.2893 & & -0.3816 & & -0.3511 & \\
\hline & $(3.51)^{* * *}$ & & $(3.89)^{* * *}$ & & $(0.74)$ & \\
\hline \multirow{2}{*}{$\operatorname{RISK}_{(i, t-1)}$} & & 0.0677 & & 0.1909 & & 0.0053 \\
\hline & & $(1.22)$ & & $(2.59)^{* * *}$ & & $(0.12)$ \\
\hline \multirow{2}{*}{$R E G$} & -0.1185 & -3.3311 & -0.2500 & 21.7593 & 0.1640 & 12.527 \\
\hline & $(1.28)$ & $(0.13)$ & $(2.13)^{* *}$ & $(0.60)$ & $(1.72)^{*}$ & $(0.33)$ \\
\hline \multirow{2}{*}{ LLOSS } & & 2.4725 & & -21.0570 & & 20.744 \\
\hline & & $(0.27)$ & & $(1.29)$ & & $(1.30)$ \\
\hline \multirow{2}{*}{$\Delta R I S K$} & -0.0026 & & 0.0004 & & 0.0030 & \\
\hline & $(0.25)$ & & $(0.60)$ & & (1.64) & \\
\hline \multirow{2}{*}{$\triangle C A R$} & & 18.628 & & 29.379 & & 7.7082 \\
\hline & & $(4.14)^{* * *}$ & & $(5.31)^{* * *}$ & & $(1.12)$ \\
\hline \multirow{2}{*}{ Intercept } & 0.431 & -7.8105 & 0.0053 & 8.5649 & 0.0703 & -30.603 \\
\hline & $(3.20)^{* * *}$ & $(0.79)$ & $(0.21)$ & $(0.68)$ & (1.53) & $(2.27)^{* *}$ \\
\hline$N$ & 230 & 230 & 110 & 110 & 120 & 120 \\
\hline$R^{2}$ & $35.65 \%$ & $15.11 \%$ & $44.42 \%$ & $24.66 \%$ & - & $6.94 \%$ \\
\hline$\chi^{2}$ & $149.44^{* * *}$ & $19.19^{* * *}$ & $76.20^{* * *}$ & $32.40 * * *$ & $32.67^{* * *}$ & $17.82 *$ \\
\hline
\end{tabular}

*: Significance at 10\%**: significance 5\%, ***: significance 1\%. N: number of observations. The Student statistic in parentheses. $\mathrm{R}^{2}$ : coefficient of determination. Chi-Square: statistical chi-square (test on the validity of the identification to restrictions) for 3SLS method. Estimation (2014) 11 with the Stata software. 
Methodologically, interpreting the results of the estimation of our model will start with an analysis of impacts exerted by exogenous variables on endogenous ones $(\triangle \mathrm{CAR})$ and ( $\triangle \mathrm{RISK})$ jointly on the total period and in parallel on the two sub periods 'analysis. Focusing throughout our reading of the results on the relationship between regulatory pressure, the level of capital ratio and that of taking the risk, we will, in the following, make a comparison of results compared to other results found in similar international contributions (see Table 6).

\subsection{Relationship between Return on Assets and Capital Ratio}

The estimation results presented in Table ( 5 show that over the entire period from 1990 to 2012, the ratio of return on assets (ROA) is positively related to the change in capital ratio. In fact, the parameter $(\alpha 1)$ is equal to $(0.65631)$, positive and statistically significant with a confidence level greater than $1 \%$. A similar incidence has been found by most previous work, particularly those Shrieves and Dahl (1992), and Aggrawal Jaques (1998), Rime (2001) and Hassan and Hussain (2004) and others. These authors have supported the idea that the quality of assets held by banks is assumed to vary in the same direction as the $\triangle \mathrm{CAR}$ ratio and is likely to improve the level of this ratio as a portion of equity will consist of deferred profits collected from one year to another. Indeed, if the average economic profitability of bank assets improved by $1 \%$ then we record a change of $50 \%$ in the capital ratio between 2001 and 2012. As reported by Nashane and Ghosh (2001), Darine ( 2008) and Saadawi (2011), institutions that generate significant profits (ie a high ROA ratio), towards the end of each year, will have to see results more comfortable and therefore a greater level of funds Regulatory own early in the following year. In our context, the first hypothesis (H1) has been verified and this result suggests that the majority of leaders of Tunisian banks generally prefer to increase their capital levels by making use of retained earnings rather than issuing new shares on the stock market. Banks seem to rely on retained earnings to increase their level of capital instead of using a new share issue, considered expensive and could be transmitted, according to the theory of financial hierarchy (Majeluf 1984) Market a bad signal (Leland and Pyle 1977) or adversely information about the market value of the banking firm in the presence of asymmetric information.

For all ten banks in our sample and the first sub-period which runs from 1990 until 2000, the variable effect (ROA) on the change in the level of $\triangle \mathrm{CAR}$ ratio is not statistically significant but we record a positive sign of parameter. Indeed, during this decade, rich mutation, is recorded profitability ratios remarkably very poor assets. For commercial banks the value of this ratio is on average about $1.2 \%$ in 2000 against $0.4 \%$ in 1990 . It seems plausible to advance that on average assets held by Tunisian banks at that time was little economically viable. This opacity detected actual quality level of assets, makes unquestionable the existence of bank issues mainly concern the side of balance sheet assets. Indeed, the deterioration in asset quality was manifested through a) increasing the level of non-performing loans, b) increased price volatility of bank assets, and c) increased probability of bankruptcy c ' is to say a very high default risk. In 2001, the report of the International Monetary Fund, realized over a period (1993-2000), analyzing the situation of the Tunisian banking sector has shown that it is to strengthen the capital base of credit institutions, safeguard their credibility and encourage them to adopt modern methods of risk assessment and management to maintain a comfortable level of performance as measured by the (ROA). Indeed, during the period (1990-2001), and following the introduction in 1991 of bank prudential regulations in Tunisia, largely inspired by international norms and standards and their tightening in 1992, identified the weaknesses of the sector and leads to develop a remediation plan for the financial situation of domestic banks to consolidate their capital base in order to meet the minimum solvency rules, prudential management through improving their portfolio quality assets as well as their organizational and institutional capacities.

The consolidation of the financial basis of Tunisian banks continued through the strengthening of the own capital and provisions favored by a favorable tax regime and a reduction in non-performing assets, such as to improve the level of banking performance detect in this paper by the ratio (ROA). The successful growth of capital policy, in accordance with the international standard, was favored by the conjunction of three factors: a) commitment in 1987 of a package of reforms introducing prudential regulation, $b$ ) an enabling environment in the financial market and c) a reasonable dividend policy in the banking sector. At this level of analysis, we cannot accept the significance of the ROA variable from the level of capital ratio of variation $(\triangle \mathrm{CAR})$ in our model and during first sub period (1990-2000). However, and in the second period beginning in 2001 and finished in 2012, the effect of the variable reflecting the return on assets (ROA), the ten banks in our sample, the variation in the level of capital ratio ( $\triangle \mathrm{CAR}$ ) become statistically significant. These results corroborate those found by Rime (2001) Van Roy (2005) Godlewski (2004), Al-Zubi et al. (2008), and Ben Hmida Bouri (2010) and Awdeh et al. (2011). We record a positive effect, a parameter equal to (0.5087) and a Student-t of about (3.40)> 1.96 (in absolute value) at a probability level of $1 \%$. The banks hold assets of good quality and exhibit more preference to raise their levels of capital ratio by profits carried forward by the use of new issues on the market. 


\subsection{Relationship between Size, Variation in Ratio of Capital and the Change in Risk Level}

The variable (SIZE) has been introduced in both equations (I.5.1) and (I.5.2) in our model respectively at the capital ratio and the level of risk taking (and $\triangle$ RISK $\triangle \mathrm{CAR}$ ) to capture the effect "size". During the entire period (1990-2012), the result of the estimation shows that this variable is statistically insignificant and the parameter $(\alpha 2)$ is negative as expected under the assumption (H2) to ( $\triangle \mathrm{CAR}$ ). Initially, a negative correlation between the variable size and variable $(\triangle \mathrm{CAR})$ has been detected for a coefficient equal to $(-0.2433)$. This result was also observed by Godlewski (2005) for 15 European banks. He did not find any size effect on the level of capital ratio. In addition, this author has found these results in a significant and negative impact of the variable (SIZE) on the level of risk ( $\triangle$ RISK). We recall that the size of ten banks identified in our sample is substantially similar. Indeed, the value of the variable (SIZE) is in a range of [12.4643 and 16.8847], an average equal to 14.81109 . We can confirm that it is almost inappropriate to cutting these facilities between "small banks" and "large banks" as performed by Shrieves and Dahl (1992), Rime (2001), Heid et al. (2005), Van Roy (2005) and Awdeh et al. (2011) and Camara (2010), in their previous econometric analyzes. Tunisian banks are all almost similar in size and even qualified small, relative to European banks or US banks, particularly in relation to the Swiss and German banks. In 2011, the Tunisian financial sector was modest in size and dominated by banks, with assets accounting for about $115 \%$ of GDP. This figure is lower than that observed in other comparable countries in the region in 2012, there were 21 domestic banks, including 03 public banks holding $37 \%$ of banking sector assets and 03 domestic private banks with $28 \%$ of total assets (These banks are part of our sample) and 06 private banks with foreign capital holding a share of $28 \%$. Four of these institutions are major foreign banks (French, Jordanian and Moroccan). Also, the volume of own funds held by ten banks in our sample selected is described as modest compared to that provided by the aforementioned foreign banks. The effect of size on the level of capital ratio, is not statistically significant in the three periods. Shrieves and Dahl (1992) insisted that the size could have an effect on capital ratios and risk levels for several reasons, such as investment opportunities of the facility, the characteristics of the combined properties with its easy access to the markets of capitaux.La majority of banks in Tunisia have easier and faster access to borrow the necessary funds on the interbank market which was confirmed for the banks in the US and by Shrieves Dahl (1992), the Swiss banks, for Rime (2001) and the European banks in the results of the work of Van Roy (2005). Regarding the level of risk taking, the results on the total period of our analysis reveal that there is no significant impact between the bank's size (SIZE) and the risk-taking behavior ( $\triangle$ RISK). The object of our research banks fail to lower their levels of risk-taking even if the volume of activity is remarkable growth, this may possibly be explained by the lack of diversification that characterizes their average asset portfolios.

This finding contradicts the one found by Aggrawal and Jacques (1998), Heid et al. (2004) for German banks and Murinde and Yassen (2004) for US banks between 1991 and 1993 and Saadawi (2010) for banks in emerging countries. Furthermore, during the second sub-period 2001-2012, the results show that the variable size effect is statistically significant with a positive sign on the variable about taking risk. We record a t-Student in the range of (2.35), significant at the $99 \%$ confidence interval (at 1\% level). The variable (RISK), represents the risk index of the bank, the higher it is the greater the risk level is low, so the positive signal detected between the change this variable (IR) and size (SIZE) of the bank Not surprisingly. So we have a negative effect between size and the level of risk as provided in (H2), only the second sub-period. Indeed, as pointed Bouri and Ben Hmida (2011) this relationship can be a sign of a recent performance of the "too big to fail" doctrine in the Tunisian context because any increase in size implies a reduction of the variation of the ratio hedging risk that is to say an increase in the risk index (RI). This result can then be interpreted as the signal of a new asset management policy dealing with nearly the volume of the bank's commitments. Aggrawal and Jacques (1998), Behr et al. (2009), Lin et al (2013) found that the size variable has a negative and significant effect on the level of capital ratio and the banks' risk level in both equations. Similarly, the results of Matejašák and Teplý (2009) exhibit a negative and significant impact of this variable on the level of capital ratio of large US and European banks. These banks have easy access to financing on the capital markets and so they usually operate with low levels of capital. Moreover, Van Roy (2005), are supported on the interpretation argument diversification of the asset portfolio which may reduce the risk level and therefore the size to a negative effect on $\triangle$ RISK variable. These results join those found by Awdeh et al (2011) for banks in Lebanon. Against by the results found by Al-zubi et al. (2008) for banks in Jordan have a positive and significant impact of the variable (SIZE) on the risk level and they argued that finding by the fact that banks large ( 24 commercial banks) have very risky assets in their balance sheets more than the smaller banks further that the disengagement major mortgage banks (50\% weighting) and the increased focus on corporate finance (100\% weighting) between 1990 and 2002. 


\subsection{Relationship between the Ratio of Non-performing Loans and the Change in Risk Level}

Given the nature of the risk-taking indicator (IR) that we have chosen, we expect that the relationship between LLOSS and $\triangle$ RISK is negative. Indeed, a risk index (RI) high is synonymous with a low level of risk. So the relationship between LLOSS variable, as expected under the assumption (H6) with the $\Delta$ RISK variable should be negative that is to say a negative impact between the level of provisioning for loan losses and changes in the level of risk. In fact, provisions are used either to cover the previously recorded losses and eliminate the total amount of loans or to cover future expected losses, resulting in a negative relationship between the volume of provisions set aside and risky behavior banks. At the correlation matrix (II.3), a negative coefficient equal to (-0.2258) was found between these two variables. Generally the riskiest banks are those provisionnent most. Moreover, this variable receives an average a value of $22.75 \%$ over the whole period (1990-2012).

This is a relatively low ratio for all ten universal banks retained. In 2009 , this ratio continued to decline to reach (13.2\%) on average. This deterioration is explained by a somewhat rigorous risk assessment by both regulators and by institutions. Similar in their work, and Shrieves Dahl (1992), and Negro Jacques (1997) and Godlewski (2005) did not introduce this variable in their specifications. By cons, and Quagliariello Cannat (2006) and Saadawi (2010) have integrated variable (LLOSS) in a model similar to ours applied on a sample composed respectively of Italian banks and banks in emerging countries. These authors emphasized that the relationship of this indicator with the level of risk taking depends on the definition of risk chosen. We also note a positive effect was recorded in the results of the estimates made by successively Awdeh et al. (2011), Al Zubi et al. (2008), Darine (2008), Lin et al. (2013), and Matejašák Teplý (2009), Van Roy (2005) and Rime (2001), and between LLOSS $\Delta$ RISK. Their results were consistent with previous studies, including those of Aggrawal and Jacques (1998) on US banks between 1991 and 1993. The banks holding bad qualities of loans, are forced to be more but these provisions remain insufficient to counteract the banking companies to engage in more risky activities and to cover their unexpected losses. In the Tunisian context, Bouri and Ben Hmida (2011) found that the change in the level of risk of poor structure of assets increases significantly with the increase in provisions for bad and doubtful debts of banks and only for up from 31 December 1999 until August 2007. Provisioning remains largely insufficient to cover the amount of loss in case of default of qualified high in Tunisia.

4.4 Relationship between the Ratio of Net Interest Margin, the Variation of the Ratio of Capital and the Change in the Level of Risk

SPREAD variable is the ratio of net interest margin on total assets of each bank (i) during the year (t). This variable was included in the model at the two equations (I.5.1) and (I.5.2), it registers negative correlation coefficients with the endogenous model variables (I.5) are respectively (-0.0525) with ( $\triangle \mathrm{CAR})$ and $(-0.0434)$ with $\triangle \mathrm{RISK}$ variable. Its average value in our sample is at (0.03631) with a standard deviation of about (0.021089). The respective coefficients in the equations of simultaneous model $(\alpha 3)$ and ( $\beta 3)$ are provided to take the respective signs $\alpha 3>0$ and $\beta 3<0$. Indeed, it is expected that the SPREAD variable is positively and significantly related the the level of capital ratio and simultaneously, should be negatively and significantly associated with the level of risk and in accordance with the hypothesis (H4) previously set. The estimation results show a positive effect of this variable, statistically significant, the variation in the level of capital ratio $\triangle$ CAR during the period under (1990-2000) and recorded a t-Student equal to (2.24) to degree of greater than $95 \%$ confidence. This can be explained by the fact that the will of the institutions to comply with regulatory capital standards depends in part on their net interest margin, which covers the cost of risk and contributes significantly to the realization of the value measured by their Net banking income. This result is supported by the one found by Saadawi (2010) for banks in emerging countries, Awdeh et al (2011) for 24 banks and Lebanese Rajhi and Gassouma (2011) in the Tunisian context. Regarding the impact of net interest margin ratio of risk-taking, the estimate shows that this variable has no significant effect for the banks in our sample over the three periods.

Through the reading of more than 28 similar contributions made to our worldwide, we noticed that the SPREAD variable has not been introduced in most of these pioneers and authors work such as Shrieves and Dahl (1992) Aggrawal and Jacques (1998), Jacques and Nigro (1997) Godlewski (2005), Heid et al (2005), Hassan and Hussain (2004) Murinde and Yassen (2004), Matejašák and Teplý (2009), Van Roy (2005) and Rime (2001) and others, this variable fails for reasons related to the weakness of its explanatory power of the level of capitalization and risk taking. They have brought against the variable (LEV) representing the financial leverage. 
4.5. Relationship between the Regulatory Pressure, the Change in the Ratio of Capital and the Change in the Level of Risk

One of the essential objectives of this article is to enlighten the simultaneous effect of regulatory pressure, through the REG variable ( $\mathrm{i}, \mathrm{t}-1)$ to the level of capitalization and the banks' behavior in terms of decision risk. This variable was introduced in both equations of the model (I.5.1) and (I.5.2), to capture the impact of regulatory requirements resulting from Basel Accords (I, II and III) on both endogenous variables $\triangle \mathrm{CAR}$ and $\triangle \mathrm{RISK}$. According to the hypothesis (H5) Regulatory pressure has a positive impact on the accumulation level (ie $\alpha 6>0$ ) but that the level of risk-taking to be determined (marked of $\beta 6$ can not be predicted). REG variable is evaluated based primarily on the work of Murinde and Yassen (2004), Van Roy (2005) and Hassan and Hussein (2006) and Matejašák and Teplý (2009). The calculates that exogenous variable was performed according to two conditions: The first a) REG i, $t$ is equal to the required regulatory minimum (Min REG) which is added the standard deviation of CAR ratio for each bank (i) ( $\sigma$ curry ) Net of the value of this ratio (curry, t) if CAR i, $t$ is less than the (Min REG) plus the standard deviation ( $\sigma$ curry) and second $b$ ) states that the REGi variable, $t$ is invalid if (curry, $t$ ) is above the regulatory minimum sum and the standard deviation of capital ratio associated with each bank (i), (Min REG $+\sigma$ CARI). On average this variable stores a value of $(0.0159)$ with a standard deviation of about 0.0185 . She breaks down, for the ten banks and over the entire period from 1990 to 2012, between zero and values $(0.1177)$. The results of the estimation of our model show that the effect of regulatory pressure is statistically significant on the level of capitalization and on the two periods under analysis: SP1 (1990-2000) and SP2: (2001 -2012). During SP1, there has been a coefficient $(\alpha 6)$ negative and equal to $(-0.25)$ with a t-Student (2.13) significant at 5\%. Whereas during SP2, the parameter $(\alpha 6)$ becomes positive equal to $(0.1640)$ and statistically significant at the $99 \%$ confidence interval is a t-Student the order of (1.72). So we can conclude that during the SP1, regulatory pressure had a negative effect on the level of the solvency ratio for Tunisian banks.

The capital ratios between 1990 and 2001 are very low compared to the required prudential standard (5\%), so we can say that the banks did not care about their solvency ratio and regulatory pressure does not induce banks to increase their capital level. This result is in line with those advanced by the majority of the above mentioned authors including Jacques and Aggrawal (1998), Jacques and Nigro (1997), Rime (2001), Van Roy (2005) Godlewski (2005), Matejašák and Teplý (2009), Jokipii and Milne (2010) and Awdeh et al. (2011). In our estimation, we recall that the regulatory minimum (Min REG) required by the Central Bank in Tunisia was 5\% during the period SP1 and then it was revised upwards in accordance with international regulatory standard to become $8 \%$ which coincides with the second sub period from 2001 to 2012. The results can be interpreted by beginning to remember that the standard of regulatory solvency was newly introduced by circular to banks No. 91-24 17/12/1991. The response of these institutions to these regulatory standards seems to be very slow and their behavior during this first period for capitalization was contrary to what is covered by the supervisory authorities. Moreover, some banks were able to conduct their activities without considering the risk management standards or key regulatory requirements. Thus, the negative effect of the variable (REG) on the level of capital ratio ( $\triangle \mathrm{CAR}$ ) during SP1, contradicts with the results found by mainly Dahl and Shrieves (1992), and Quagliariello Cannat (2006), Chiurri stall. (2001) and Mongid et al. (2012), but corroborates the outcomes of Heid et al. (2004), and Murinde Yaseen (2004). During SP2, the effect of regulatory requirements set by the $\mathrm{BCT}$ on equity on the level of capital ratio is positive and statistically significant at a confidence level greater than $1 \%$. Regulatory pressure (REG) results in an improvement of the ratio ( $\triangle \mathrm{CAR}$ ) This result is similar to that obtained by Murinde and Yaseen (2004) Ayachi Jabnoun (2006), Heid et al. (2005). Indeed, during this period there has been a change in the regulatory minimum solvency becomes $(8 \%)$ instead of (5\%) previously with the appearance of the new circular to banks $n{ }^{\circ}$ 99-04 of March 19, 1999 which aims division, risk hedging and monitoring of commitments. The higher the level of capital approach the regulatory minimum, most banks will feel obliged to adjust their capital levels in order to escape restrictions and sanctions legislative measures. These penalties are provided by section 42 of the Banking Law No. 2006-19 of May 2, 2006. The breaches of banking legislation and regulation continued at the initiative of the Governor of the Central Bank of Tunisia and expose credit institutions found guilty of sanctions ranging from warnings to the withdrawal of approval. It is reported that the results of our estimates show that the effect of the REG variable on the level of risk-taking is not statistically significant in the three periods of analysis. Banks, as they comply with the prudential standard for capital requirement, they do not care too much what the level of risk in their activities engaged in it. Moreover, they are invited to reduce their risk levels to avoid regulatory costs caused by non-compliance with regulatory requirements on capital. This result suggests that the banks in our sample are not ready to reduce their risk-taking not break the regulations. The minimum capital requirements are too low in relation to risks to the Tunisian banking system. 
The effect of this variable on the level of risk was ambiguous right from the start. However, Ediz et al. (1998), Rime (2001) Nachane and Ghosh (2001), Elosegui and Pentiris (2002), Blum and Bichsel (2004), Van Roy (2005), Darine (2008), Matejašák and Teplý (2009), Jokipii and Milne (2010) and Mongid et al (2012) also found an identical result to ours in other similar contexts estimate simultaneous equations: regulatory pressure has no effect on the level of incitement taking the overall risk of the bank.

\subsection{Relationship between the Variation of the Ratio of Capital and the Change in the Level of Risk}

The first hypothesis (H1), based on the conclusions drawn from the review of theoretical and empirical literature on the simultaneous relationship between the level of capital ratio $(\triangle \mathrm{CAR})$ and the risk level $(\triangle \mathrm{RISK})$ indicates that this behavior exhibits a negative association in the first sense ( $\triangle$ CAR on $\triangle$ RISK) but the impact of return remains nuanced and unexpected ( $\triangle \mathrm{RISK}$ on $\triangle \mathrm{CAR}$ ). In fact a non-linear relationship $\mathrm{U}$ is also provided between these two endogenous variables. In fact, the respective coefficients of these variables are $(\alpha 4)$ and $(\beta 4)$ on the capitalization and risk, in equations (I.5.1) and (I.5.2) of our specification, will have positive signs for the first (because there is a risk index IR) and positive or negative for the second. Thus, a positive sign $(\alpha 4)$ means a negative impact of the change in the capital ratio on the risk level of the selected banks. The results obtained in our estimates show that the total period (1990-2012), the change in the ratio of regulatory capital ( $\triangle$ CAR) has a significant and negative impact on the risk-taking behavior ( $\triangle$ RISK) and statistically significant with a t-Student in the order of (4.14) to a confidence level greater than $1 \%$. This result suggests that the banks in our sample do not seem to behave according to the expectations of regulatory authorities. Indeed, a rise in the level of risk ( $\triangle \mathrm{RISK}$ ) $1 \%$ results in a decrease in the level of capitalization of a proportion of the order of (18 628) points at a $99 \%$ confidence level. He acted very fast discretionary adjustment in the opposite direction. During this period the increase in regulatory capital results in a significant decrease in risk taking. This negative impact corroborates the results obtained by Nachane and Ghosh (2001), Abhiman and Ghosh (2004), Hussain and Hassan (2005) and Cannat and Quagliariello (2006), Darine (2008), Al Zubi et al. (2008) and Jokipii and Milne (2010) and Mongid et al. (2011). In addition, the contribution of Zhang et al (2008) establishes a negative relationship between capital ratio and the propensity of banks to take risks. The higher the ratio level is high and less banks engage in risky activities. This has allowed us to justify the basis of the impact of regulatory pressure. The estimation of the model in a period (SP1) also shows a negative and statistically significant significant effect (with a positive sign) of the capital ratio ( $\triangle \mathrm{CAR}$ ) on the risk-taking behavior ( $\triangle$ RISK).

Table 6. Comparison of our results with other similar studies

\begin{tabular}{|c|c|c|c|c|c|c|}
\hline Auteurs & Year & Sample and data & $\begin{array}{c}\text { Impact of } \\
\text { REG on } \triangle \mathrm{CAR}\end{array}$ & $\begin{array}{c}\text { Impact of } \\
\text { REG on } \triangle \text { RISK }\end{array}$ & $\begin{array}{c}\text { Impact of } \\
\Delta \text { CAR on } \triangle R I S K\end{array}$ & $\begin{array}{c}\text { Impact of } \\
\Delta \text { RISK on } \triangle C A R\end{array}$ \\
\hline Maraghni H. & 2016 & $\begin{array}{l}10 \text { (Tunisia) } \\
1990-2012\end{array}$ & + & 0 & - & 0 \\
\hline $\begin{array}{l}\text { Shrieves and } \\
\text { Dahl }\end{array}$ & 1992 & $\begin{array}{l}1800 \text { (USA) } \\
1984-1986\end{array}$ & + & - & + & + \\
\hline $\begin{array}{l}\text { Jacques and } \\
\text { Nigro }\end{array}$ & 1997 & $\begin{array}{l}2570 \text { (USA) } \\
1990-1991\end{array}$ & + & - & + & - \\
\hline $\begin{array}{l}\text { Aggrawal } \\
\text { and Jacques }\end{array}$ & 1998 & $\begin{array}{l}2552 \text { (USA) } \\
1991-1993\end{array}$ & + & - & $+/-$ & $+/-$ \\
\hline $\begin{array}{l}\text { Ediz, } \\
\text { Michael and } \\
\text { Perraudin }\end{array}$ & 1998 & $\begin{array}{l}94(\mathrm{UK}) \\
1989-1995\end{array}$ & + & 0 & + & - \\
\hline Rime & 2001 & $\begin{array}{l}154 \text { (Suisse) } \\
1989-1996\end{array}$ & + & 0 & + & + \\
\hline $\begin{array}{l}\text { Nachane and } \\
\text { Ghosh }\end{array}$ & 2001 & $\begin{array}{l}27 \text { (Inde) } \\
1997-1998\end{array}$ & + & 0 & - & - \\
\hline Penteris & 2001 & USA 1994-1999 & + & - & + & 0 \\
\hline $\begin{array}{l}\text { Chiurri, } \\
\text { Ferri and } \\
\text { Majnoui }\end{array}$ & 2001 & $\begin{array}{l}16(\mathrm{PE}) \\
1989-1995\end{array}$ & + & - & + & 0 \\
\hline
\end{tabular}




\begin{tabular}{|c|c|c|c|c|c|c|}
\hline $\begin{array}{l}\text { Elosegui and } \\
\text { Penteris }\end{array}$ & 2002 & $\begin{array}{l}\text { Argentine } \\
1996-1999\end{array}$ & + & 0 & + & + \\
\hline $\begin{array}{l}\text { Heid, Porath } \\
\text { and Slotz }\end{array}$ & 2004 & $\begin{array}{l}550 \text { (Allemagne) } \\
1994-2002\end{array}$ & - & - & 0 & - \\
\hline $\begin{array}{l}\text { Murinde and } \\
\text { Yassen }\end{array}$ & 2004 & $\begin{array}{l}98(\mathrm{MOAN}) \\
1995-2002\end{array}$ & - & $+/-$ & 0 & - \\
\hline $\begin{array}{l}\text { Blum and } \\
\text { Bichsel }\end{array}$ & 2004 & $\begin{array}{l}19 \text { (Suisse) } \\
1990-2002\end{array}$ & + & 0 & + & 0 \\
\hline $\begin{array}{l}\text { Hussain and } \\
\text { Hassan }\end{array}$ & 2005 & $\begin{array}{l}300(\mathrm{PE}) \\
1994-1997\end{array}$ & - & - & - & - \\
\hline Godlewski & 2005 & $\begin{array}{l}2779(\mathrm{PE}) \\
1996-2001\end{array}$ & + & - & + & 0 \\
\hline Van Roy & 2005 & $\begin{array}{l}576 \mathrm{G} 10 \\
1988-1995\end{array}$ & + & 0 & $+/-$ & 0 \\
\hline $\begin{array}{l}\text { Ayachi, } \\
\text { Jabnoun }\end{array}$ & 2006 & $\begin{array}{l}15(\mathrm{PE}) \\
1998-2000\end{array}$ & - & - & - & - \\
\hline $\begin{array}{l}\text { Cannat and } \\
\text { Quagliariello }\end{array}$ & 2006 & $\begin{array}{l}500 \text { (Italie) } \\
1994-2003\end{array}$ & + & + & - & + \\
\hline $\begin{array}{l}\text { Bouri and } \\
\text { Ben Hmida }\end{array}$ & $2006 / 2011$ & $\begin{array}{l}14 \text { (Tunisie) } \\
1992-2005 / 1988 \\
-2007\end{array}$ & 0 & + & 0 & + \\
\hline Darine & 2008 & $\begin{array}{l}13(\mathrm{MOAN}) \\
2000-2007\end{array}$ & + & 0 & - & 0 \\
\hline $\begin{array}{l}\text { Al Zubi and } \\
\text { al. }\end{array}$ & 2008 & $\begin{array}{l}24 \text { (Jordanie) } \\
1990-2003\end{array}$ & + & + & - & - \\
\hline $\begin{array}{l}\text { Matejašák } \\
\text { and Teplý }\end{array}$ & 2009 & $\begin{array}{l}1263 \text { (EU et } \\
\text { USA) 2000-2005 }\end{array}$ & + & $0 /-$ & + & + \\
\hline Saadaoui & 2010 & $\begin{array}{l}307(29 \text { PE) } 1995 \\
-2005\end{array}$ & 0 & - & + & + \\
\hline $\begin{array}{l}\text { Jokipii and } \\
\text { Milne }\end{array}$ & 2010 & $\begin{array}{l}8000 \text { (USA) } \\
1986-2008\end{array}$ & + & 0 & - & + \\
\hline $\begin{array}{l}\text { Awdeh and } \\
\text { al. }\end{array}$ & 2011 & $\begin{array}{l}41 \text { (Liban) } \\
1996-2008\end{array}$ & + & + & + & + \\
\hline $\begin{array}{l}\text { Ramassur } \\
\text { and Polodoo }\end{array}$ & 2011 & $\begin{array}{l}9 \text { (Maurice) } \\
2000-2008\end{array}$ & 1 & l & + & 0 \\
\hline $\begin{array}{l}\text { Mongid and } \\
\text { al. }\end{array}$ & 2012 & $\begin{array}{l}668 \text { (Asie) } \\
2003-2008\end{array}$ & + & 0 & - & - \\
\hline $\begin{array}{l}\text { Lin, Xie, } \\
\text { Wang and } \\
\text { Hwang }\end{array}$ & 2013 & $\begin{array}{l}366(\text { USA) }+235 \\
\text { (non USA) } \\
2003-2009\end{array}$ & + & - & + & + \\
\hline
\end{tabular}

Source: Done by the authors sign (+): Positive effect, sign (-): Negative Effect (0): No significant impact, +/- Effect depends on the chosen specification, REG: regulatory pressure, $\triangle \mathrm{CAR}$ : changes in the level of capital ratio, $\triangle$ RISK: changes in the level of risk. MENA: Middle East and North Africa, PE: emerging countries, USA: US, EU: European Union.

\section{Conclusions}

The objective of this paper was starting to find some answers on the simultaneous impact of the change in the capital ratio on risk-taking behavior of Tunisian banks in the light of regulatory pressure shown by the prudential requirements capital adequacy. The results basically show that on the one hand, regulatory pressure led to the adoption of the adequacy of the required capital, implies neither a decrease nor increase the incentive to risk taking 
the object of banks this article and the other, the legal and institutional mechanism shows a positive and significant effect on the level of capital ratio.

Regulatory pressure seems to exert the desired effect on the behavior of banks on the side of capital. Any change in the risk level does not induce any effect on the level of capital ratio. These banks have a preference for risk, but the effort is still insufficient capitalization. This behavior portends the existence of moral hazard in banks caused by the safety net and increased assistance for the protection guaranteed by the Central Bank.

Furthermore, by enhancing their level of capital, these banks significantly reduce their risk taking indicating a high risk aversion exhibited by shareholders and or executives. Improving the banking regulatory solvency ratio is carried out by acting on the numerator of the ratio. That is to say, if these institutions increase the level of capital bases further and, while the decline in the denominator of the ratio, measuring the level of risk will be an obvious consequence (risk-adjusted assets) which reinforces $d$ benefit their solvency levels. In this paper we have focused on banking risk by calculating a risk index closely linked to the probability of bankruptcy. View the multitude of risks that threatened the banking business in general, it is important to refine our empirical investigations with particular emphasis on taking credit risk to detect the behavior of the banking firms in Tunisia in terms of funding and pressure regulatory.

\section{Acknowledgements}

A special thank to Dr. SEHIMI MRIZIG Dhifallah, Dean of Community College of Khaybar and Professor at Taibah University, for his precious help and assistance, provided during the research, that greatly improved the manuscript.

\section{References}

Abhiman, D., \& Ghosh, S. (2004). The relationship between risk and capital: Evidence from Indian public sector banks. Economics Working Paper, Archive 0410006, EconWPA.

Acharya, V., Hasan, I., \& Saunders, A. (2002). The effects of focus and diversification on Action on Bank Capital and Risk: Estimates using a Simultaneous Equations Model. Journal of Banking and Finance, 1139-1160.

Aggarwal, R., \& Jacques, K. (1998). A Simultaneous Equation Estimation of the Impact of Prompt Corrective Action on Banking Capital and Risk. Paper Presented at the Conference on the Future of Capital in New York.

Aggarwal, R., \& Jacques, K. (2001). The impact of FDICIA and prompt corrective action on bank capital and risk: Estimates using simultaneous equations model. Journal of Banking and Finance, 25, 1139-1160.

Aggarwal, R., \& Jacques, K. T. (1998, Oct.). Assessing the impact of prompt corrective action on bank capital and risk. Economic Policy Review.

Agoraki, M.E.K., Delisb, M.D., \& Pasiourasc, F. (2010). Regulations, competition and bank risk-taking in transition countries. Journal of Financial Stability, 7(1), 38-48.

Al-Zubi, K., Mohammad, A., \& Hanadi, A. (2008). Capital Adequacy, Risk Profiles and Bank Behaviour: Empirical Evidence from Jordan. Jordan Journal of Business Administration, 4(1).

Arellano, M., \& Bond, S. (1991). Some Tests of Specification for Panel Data: Monte Carlo Evidence and an Application to employment equations. Review of Economic Studies, 58, 277-229.

Awdeh, A., El-Moussawi, C., \& Machrouh, F. (2011). The Effect of Capital Requirements on Banking Risk. International Research Journal of Finance and Economics, (66).

Ayachi, S. Jabnoune. (2006). Environnement réglementaire, risque et rentabilité des banques: cas des pays émergents. Rapport technique, Université Paris 10 Nanterre.

Bank of International Settlements. (2012). Results of the comprehensive quantitative impact study. Basel Committee on Banking Supervision, December. Retrieved from http://www.bis.org/publ/bcbs186.pdf

Barth, J. R., Caprio, Jr. G., \& Levine, R. (2006). Rethinking Bank Regulation. Till Angels Govern, Cambridge University Press.

Behr, P., Schmidt, R.H., \& Xie, R. (2009). Market structure, capital regulation and bank risk taking. Journal of Financial Services Research, 37, 131-158.

Ben, H.A., \& Bouri, A. (2011). Réglementation prudentielle et comportements des banques: Etude dans le contexte tunisien. revue comptable et financière $\mathrm{N}^{\circ} 7-2011$, recherche en comptabilité et finance. 
Bichsel, R., \& Blum, J. (2004). The Relationship between Risk and Capital in Swiss Commercial Banks: A panel study. Working Paper, Zurich, Switzerland: Swiss National Bank.

Bischel, R., \& Blum, J. (2004). Capital regulation of banks: where do we stand and where are we going?. Swiss National Bank, Quarterly bulletin, December 42-51.

Blum, J. (1999). Do capital adequacy requirements reduce risks in banking?. Journal of Banking and Finance, 23, 755-771.

Bourbonnais, R. (2003 et 2004). Econométrie. édition Dunod, Paris.

Bouri, A., \& Ben, H.A. (2006). Capital and risk taking of banks under regulation: A simultaneous equations approach in the Tunisian context. Proposition pour le sixième congrès international de l'AFFI: Finance d'entreprise et finance de marché: Quelles complémentarités?, March.

Bouri, A., \& Ben, H.A. (2006, June). Liens Entre les Fonds Propres Bancaires, La Réglementation Prudentielle et le Risque de Crédit Dans le Contexte Tunisien: Une Approche en Termes de Causalité. Euro Mediterranean Economics And Finance Review, 1(3).

Boyd, J.H., \& Graham, S.L. (1988). The profitability and risk effects of allowing bank holding companies to merge with other financial firms: a simulation study. Federal Reserve Bank of Minneapolis, Quarterly Review, 10, 2-17.

Calem, P., \& Rob, R. (1999). The Impact of Capital-Based Regulation on Bank Risk-Taking. Journal of Financial Intermediation, 8, 317-352.

Camara, B.N. (2010). Réglementation prudentielle et risque bancaire: Incidence de la structure du capital réglementaire. Thèse de Doctorat (Dirigée par Tarazi A.), FSE Limoges, France.

Cannata, F., \& Quagliariello, M. (2006). Capital and risk in Italian banks: A simultaneous equation approach. Journal of Banking Regulation, 7, 283-297.

Chiuri, M.C., Ferri, G., \& Majnoni, G. (2002). The macroeconomic impact of bank capital requirements in emerging economies: Past evidence to assess the future. Journal of Banking and Finance, 26, 881-904.

Dahl, D., \& Shrieves, R. (1990). The Impact of Regulation on Bank Equity Infusions. Journal of Banking and Finance, 1209-1228.

Darine, Y. (2008). L'impact de l'environnement institutionnel et de la régulation bancaire sur le comportement et l'efficacité bancaire: le cas de la région MENA.

Davidson, R., \& MacKinnon, J. G. (1993). Estimation and Inference in Econometrics, New York, Oxford University Press.

De coussergues, S. (2002). Gestion de la banque. édition DUNOD, paris, pp. 155-156

Demirguc-Kunt, A., \& Huizinga, H. (2000). Financial structure and bank profitability. Policy Research Working Paper 243.

Demsetz, R.S., Staidenberg, M.R., \& Strahan, P.E. (1997). Banks with Something to Lose: The Disciplinary Role of Franchise Value. Economic Policy Review, 2(2), 1-14.

Dewatripont, M., \& Tirole, J. (1993). The Prudential Regulation of Banks. MA, MIT Press: Cambridge. USA.

Dietsch, M., \& Tilloy, L. (2014). Les buffers contracycliques dans les banques commerciales. Revue Banque \& StratEgie ${ }^{\circ} 287$.

Ediz, T., Michael, I., \& Perraudin, W. (1998). Bank Capital Dynamics and Regulatory Policy, Paper Presented at the Conference on the Future of Capital in New York (February).

Ediz, T., Michael, I., \& Perraudin, W. (1998, October). The impact of capital requirements on U.K. bank behavior. Economic Policy Review, Federal Reserve Bank of New York, 15-22.

Elosegui, P., \& Pentiris, G. (2002). Privatization, Foreign Entry, and Bank Risk in an Emerging Banking System: The Case of Argentina, 1996-1999. The University of Illinois. Midwest Finance Association 2002 meetings and BCRA seminar 2002.

Esty, B. (1997), Organizational form and risk-taking in the savings and loan industry. Journal of Financial Economics, 44, 25-55. 
Ghosh, S. (2009). Bank risk, charter value and depositor discipline: A simultaneous equations approach. Applied Economics Letters, 16(6), 639-644.

Ghosh, S., Nachane, D., Narain, A., \& Sahoo, S. (2003). Capital Requirements and Bank Behavior: An Empirical Analysis of Indian Public Sector Banks. Journal of International Development, 15, 145-156.

Godlewski, C.J. (2004). Capital Regulation and Credit Risk Taking: Empirical Evidence from Banks in Emerging Market Economies. University of Strasbourg Working Paper.

Godlewski, C.J. (2004). Le rôle de l'environnement réglementaire, légal et institutionnel dans la défaillance des banques le cas des pays émergents. Banque et Marche's, 73, 20-31.

Godlewski, J.C. (2005). Bank capital and credit risk taking in emerging market economies. Journal of Banking Regulation, 6(2), 128-145.

Goodhart, C.A.E., \& Sunirand, P. (2003). A model to analyse financial fragility: applications. Journal of Financial Stability, 1, 1-30.

Goyeau, D., \& Tarazi, A. (1992). Evaluation du risque de défaillance bancaire en Europe. Revue Economique, 102, 250-280.

Guidara, R., Soumaré, D., \& Son, L.K. (2010). Performance, Risk and Capital Buffer under Business Cycles and Banking Regulations:Evidence from the Canadian Banking Sector, Version préliminaire (2010).

Hannan, T. H., \& Hanweck, G. A. (1988). Bank insolvency risk and the market for large certificates of deposit, Journal of Money, Credit, and Banking, 20, 203-211.

Heid, F., Porath, D., \& Stolz, S. (2003 et 2004). Does capital regulation matter for bank behavior? Evidence for German savings banks. Working Papers, Kiel Institute for World Economics, ${ }^{\circ} 1192$. Deutsche Bundesbank, Germany. Banking and Financial Studies no. 3.

Hood, W. C., \& Koopmans, T.C. (1953). The estimation of simultaneous linear economic relationships. Chapter IV, 112-199.

Hussain, M.E., \& Hassan, M.K. (2006). Basel capital requirements and bank credit risk taking in developing countries. Working paper, University of New Orleans/Drexel University, LeBow College of Business, Department of Finance.

Jacques, K., \& Nigro, P. (1997). Risk-based capital, portfolio risk and bank capital: A simultaneous equations approach. Journal of Economics and Business, 49, 533-547.

Jokipii, T., \& Milne, A. (2008). The cyclical behaviour of European bank capital buffers. Journal of Banking and Finance, 32(8), 1440-1451.

Jokipii, T., \& Milne, A. (2010). Bank capital buffer and risk adjustment decisions. Journal of Financial Stability, 165-178.

Kaddour, H., \& Jacoud, G. (2010). Bank internationalisation and crisis. communication à l'International Conference Russia and Europe: Global Changes and Modern Development organisée à Saratov (Russie) les 12-14 avril 2010.

Klein, M. (1955). A theory of the banking firm. Journal of Money, Credit and Banking, 3, 205-218.

Konishi, M., \& Yasuda, Y. (2004). Factors affecting bank risk taking: Evidence from Japan. Journal of Banking and Finance, 28(1), 215-232.

Koopmans, T. C. (1950). Statistical interference dynamic models. John Wiley et Sons, Inc., New York Chapman \& Hall, Limited, London.

Laeven, L., \& Levine, R. (2009). Bank governance, regulation, and risk taking. Journal of Financial Economics, 93, 259-275.

Leland, H., \& Pyle, D., (1977). Information Asymmetries, Financial Structure and Financial Intermediaries. Journal of Finance, 32, 371-387.

Liang, N., \& Rhoades, S. A. (1991). Asset diversification, firm risk and risk-based capital requirements in banking. Review of Industrial Organization, (6), 49-59. 
Lin, S.L., Hwang, D.Y, Wang, K.L., \& Xie, Z.W. (2013). Banking Capital and Risk-taking Adjustment under Capital Regulation: The Role of Financial Freedom, Concentration and Governance Control. International Journal of Management, Economics and Social Sciences, 2, 99-128.

Mamoghli, C., \& Dhouibi, R. (2009). Accounting and capital market measures of banks' risk: evidence from an emerging market. Banks and Bank Systems, 4(4).

Matejašák, M., \& Teplý, P. (2009). Regulation of bank capital and behavior of banks: Assessing the US and the EU-15 region banks in the 2000-2005 period. IES Working Paper, 23/2009, IES FSV, Charles University.

McAllister, P., \& McManus, D. A. (1993). Resolving the Scale Efficiency Puzzle in Banking. Journal of Banking and Finance, 17(2-3).

Mercieca, S., Schaeck, K., \& Wolfe S. (2007). Small European banks: Benefits from diversification?, Journal of Banking Finance, 31, 1975-1998.

Michael, S. (1984). Tobin's Q unionization and the concentration-profits relationship, Rand Journalof Economics, 15, 159-70.

Mitchell, B. (1998). Bank equity stakes in borrowing firms and financial distress. Working Papers, Federal Reserve Bank of Philadelphia 96-1, Federal Reserve Bank of Philadelphia.

Mongid, A., Tahir, I.Z., \& Haron, S. (2012). The Relationship between Inefficiency, Risk and Capital: Evidence from Commercial Banks in ASEAN. Int. Journal of Economics and Management, 6(1), 58-74.

Murinde, V., \& Yaseen, H. (2004). The Impact of Basle Accord Regulations on Bank Capital and Risk Behaviour: 3D Evidence from the Middle East and North Africa (MENA) Region. University of Birmingham.

Nachane, D.M., \& Ghosh, S. (2001). Capital Adequacy Requirements and the Behaviour of Commercial Banks in India: An Analytical and Empirical Study. DRG Study No 22, Reserve Bank of India, Mumbai. Reserve Bank of India: Statistical Tables Relating to Banks in India (various years).

Noss, J., \& Toffano, P. (2014). Estimating the impact of changes in bank capital requirements during a credit boom. Bank of England Working Paper, forthcoming.

Pelzaman, S. (1970). Capital Investment in Commercial Banking and its Relation to Portfolio Regulation. Journal of Political Economy, 78, 1-26.

Powell, A. (2004). Basel II and developing countries: sailing through the sea of standards. Policy Research Working Paper, the World Bank, n³387, septembre.

Rajhi, M.T., \& Gassouma, M.S. (2011). Rapprochement entre capital réglementaire et capital économique dans les banques Tunisiennes dans le cadre du passage du Bâle I au Bâle II. Journal of Academic Finance, 2, Spring 2011.

Rajhi, M.T., \& Mahouachi, S. (2002). Régultation du capital et du risque des banques. mémoire de DEA, FSEG -Tunis. $2002-2003$.

Rajhi, M.T., \& Maraghni, H. (2001). Respect des normes prudentielles et son impact sur la solvabilité des banques commerciales tunisiennes. Mémoire d'Etudes Approfondies et Finance, janvier 2001.FSEG Tunis. (Direction de M.T. RAJHI).

Ramessur, T.S., \& Polodoo, V. (2011). The Impact of Basel Risk Based Capital Requirement (Accord I) on Bank Performance in the Context of a Small Service-Based Island Economy. International Journal of Small Economies, 2(1), 15-35.

Rime, B. (2001). Capital requirements and bank behaviour: Empirical evidence for Switzerland. Journal of Banking and Finance, 25, 789-805.

Rochet, J.C. (1999). Solvency regulations and the management of banking risks. European Economic Review, 43, 981-990.

Rochet, J.C. (2008). Procyclicality of financial systems: is there a need to modify current accounting and regulatory rules?. Revue de Stabilité Financière, $n^{\circ}$ 12, Banque de France, Paris (octobre).

Rochet, J.C. (2008). Why are There so Many Banking Crises?. Princeton University Press, Princeton USA.

Roy, P.V. (2005). The impact of the 1988 Basel Accord on banks capital ratios and credit risk- taking: an international study, Finance 0509013. Economics Working Paper Archive EconWPA. 
Saadaoui, Z. (2010). Capitalisation et prise de risque des banques dans les pays émergents. Brussels economic rewiew - cahiers économiques de Bruxelles, 53(3/4), Autumn-winter.

Santos, J. (2001). Bank capital regulation in contemporary banking theory: A review of the literature. Financial Markets, Institutions and Instruments, 10, 41-84.

Sargan, J. D. (1958). The estimation of economic relationships using instrumental variables. Econometrica, 26, 391-393.

Saunders, A., E., Strock, N. G., \& Travlos. (1990). Ownership structure, deregulation, and bank risk taking. Journal of Finance, 45, 643-654.

Sinkey, J. Jr. (1999, September). Problem and Failed Institutions in the Commercial Banking Industry. Prentice Hall International Paperback Editions.

Solhi, S., \& Mehdi, A. (2012). Prevention Du Risque De Defaillance Des Banques De La Region MENA: Analyse Par Equations Simultanees En Donnees De Panel. Corruption and economic development Erf 18th annual conference March 25-27, 2012 Cairo, Egypt.

Stiroh, K. (2006). A portfolio view of banking with interest and noninterest assets. Journal of Mone Credit and Banking, 38, 1351-1361.

Tarazi, A, Goyeau, D., \& Sauviat, A. (1998, May-June). Size, Return and Bank Risk: Empirical test and Prospects for Prudential Regulation. Revue Economie Politique, 108(3).

Tarazi, A. (2003, May). Contrôle prudentiel et détection des difficultés financières des banques: quel est l'apport de l'information de marché?. with I. Distinguin et Ph. Rous. Revue Economique, 57(3).

Tarullo, D. (2008, July). Banking on Basel: The Future of International Financial Regulation. Peterson Institute.

Taylor, A., \& Goodhart, C. (2004). Procyclicality and volatility in the financial system: the implementation of Basel II and IAS 39. London School of Economics, FMG Discussion Paper.

Tirole J. (2008, December). Leçons d'une crise. TSE Note, (1).

Xue, Yin, \& Zhang. (2013, June). A study on bank risk-taking behaviors under the capital regulation and constraints of bank asset allocation strategies. MDHSS2013, 1332-1346.

Zellner, A. (1962). An efficient method of estimating seemingly unrelated regression and tests for aggregation bias. Journal of the American Statistical Association, 57(298), 348-368.

Zellner, A., \& Theil, H. (1962). Three Stage Least Squares: Simultaneous Estimation of Simultaneous Equations. Econometrica, 30(1), 54-78. 